\title{
REVIEW ARTICLE \\ Wohlfahrtiimonas chitiniclastica: current insights into an emerging human pathogen
}

\author{
P. SCHRÖTTNER ${ }^{1 *}$, W. W. RUDOLPH ${ }^{2}$, U. DAMME ${ }^{3}$, C. LOTZ ${ }^{4}$, E. JACOBS ${ }^{1,2}$ \\ AND F. GUNZER ${ }^{1,2}$ \\ ${ }^{1}$ Institut für Medizinische Mikrobiologie und Hygiene, Medizinische Fakultät Carl Gustav Carus, TU Dresden, \\ Dresden, Germany \\ ${ }^{2}$ Institut für Virologie, Medizinische Fakultät Carl Gustav Carus, TU Dresden, Dresden, Germany \\ ${ }^{3}$ Medizinische Klinik und Poliklinik 3, Universitätsklinikum Carl Gustav Carus, Dresden, Germany \\ ${ }^{4}$ Klinik und Poliklinik für Dermatologie, Universitätsklinikum Carl Gustav Carus, Dresden, Germany
}

Received 18 August 2016; Final revision 26 October 2016; Accepted 21 December 2016; first published online 6 February 2017

\section{SUMMARY}

Since the first description of Wohlfahrtiimonas chitiniclastica in 2008, a number of well described case reports demonstrating its pathogenic role in humans have been published. Infections may be closely linked to flies, such as Wohlfahrtia magnifica, Lucilia sericata, Chrysomya megacephala or Musca domestica. These insects are potent vectors for the distribution of $W$. chitiniclastica causing local or systemic infections originating from wounds infested with fly larvae. However, other potential sources of transmission of $W$. chitiniclastica have been described such as soil or chicken meat. Infections in humans reported to date comprise wound infections, cellulitis, osteomyelitis and sepsis. This review summarizes all the literature available up to now and gives the current knowledge about this emerging human pathogen. Additionally, four patients with proven W. chitiniclastica infections treated at Dresden University Hospital between 2013 and 2015, are included. Special focus was placed on microbiological identification and antibiotic susceptibility testing of the pathogen.

Key words: Antibiotic treatment, diagnostics, epidemiology, MALDI-TOF MS, resistance testing, Wohlfahrtiimonas chitiniclastica.

\section{INTRODUCTION}

Wohlfahrtiimonas (W.) chitiniclastica was first described by Tóth et al. in 2008. The strain was isolated from a homogenate of larvae of the fly Wohlfahrtia (Woh.) magnifica [1]. These flies are ectoparasites, which are fully dependent on the host to complete their life cycle (obligate parasites). They

\footnotetext{
* Author for correspondence: Dr P. Schröttner, Institut für Medizinische Mikrobiologie und Hygiene, Medizinische Fakultät Carl Gustav Carus, TU Dresden, Fetscherstr. 74, 01307 Dresden, Germany.

(Email: percy.schroettner@tu-dresden.de)
}

are an important cause of myiasis in both animals and humans [2]. For the bacterial isolate Tóth and co-workers proposed the name Wohlfahrtiimonas gen.nov. and defined $W$. chitiniclastica as the first species [1]. In 2014 Lee et al. described an additional species named $W$. larvae [3].

$W$. chitiniclastica are Gram-negative, strictly aerobic and non-motile rods, which lack the ability to form endospores [1]. The optimal growth temperature is between $28{ }^{\circ} \mathrm{C}$ and $37{ }^{\circ} \mathrm{C}$ [1]. Both catalase and oxidase reaction are positive while tests for urease, indole and $\mathrm{H}_{2} \mathrm{~S}$ are negative [1]. A strong chitinase activity is an important characteristic. This enzyme may play a 
role in the metamorphosis of the fly suggesting a symbiotic relationship between the insect and the bacterium $[1,4]$. Additionally, there is a close relationship between $W$. chitiniclastica and Ignatzschineria larvae (bacteria which also express chitinase and are linked to larvae as well) [5]. Up to now a few case reports have been published suggesting that $W$. chitiniclastica itself is pathogenic for humans and may be the cause of severe diseases such as bloodstream infections or osteomyelitis $[4,6,7]$. Bacteria are thought to be transmitted through fly larvae in traumatic skin lesions and/or mucosal surfaces of the host $[2,8]$. In this review, we summarize the current reports on human infections caused by $W$. chitiniclastica. All available literature is included and furthermore, we present four of our own cases of human $W$. chitiniclastica infections from patients treated at Dresden University Hospital between 2013 and 2015.

\section{SEARCH STRATEGY}

\section{Search}

A literature search in PubMed, using the following key words, was performed: 'Wohlfahrtiimonas chitiniclastica', 'Wohlfahrtiimonas chitiniclastica AND infection', 'Wohlfahrtiimonas chitiniclastica AND human', 'myiasis AND Wohlfahrtia magnifica'. All studies published since the first description of $W$. chitiniclastica in 2008 were included up to August 2016. All references cited in the relevant articles were evaluated according to their relevance for the topic of this review.

\section{Selection}

All case reports describing human infections caused or associated with $W$. chitiniclastica were included together with the first description of the bacterial strain. Furthermore, relevant articles about Woh. magnifica and myiasis were selected.

\section{Inclusion of own data}

In addition to the results obtained from the literature search we included data from four patients treated at the Dresden University Hospital between 2013 and 2015. In all these cases $W$. chitiniclastica was confirmed using matrix-assisted laser desorption/ionization time-of-flight mass spectrometry (MALDI-TOF MS; Bruker Daltonics, Germany) and sequencing of the 16S rRNA gene. It transpired that the VITEK
2 system (bioMérieux, Germany), also used in our laboratory, constantly misidentified the investigated strains, assigning different and false species names to them.

\section{RESULTS}

\section{Cases}

Eight case reports dealing with $W$. chitiniclastica infections in humans were identified by PubMed search using the search term 'Wohlfahrtiimonas chitiniclastica AND human'. One of the reports, however, describes a fatal outcome of a $W$. chitiniclastica infection in a deer [8] in the USA, and another publication reports on a dolphin suffering from endocarditis [9]. Additionally, in a recently published case report hoof cellulitis of a cow is presented [10]. These three reports on veterinary cases did not meet our search criteria since we wanted to include only human infections. In contrast, the search criterion 'Wohlfahrtiimonas chitiniclastica AND infections' revealed only seven cases including the above-mentioned two zoonotic cases. Using 'Wohlfahrtiimonas chitiniclastica' as a search criterion alone, produced 12 results, including the initial description by Tóth et al. [1]. Furthermore, another publication about the pathogen's occurrence in the insect species Hermetia illucens [3] and a report on a whole genome sequence of a $W$. chitiniclastica strain [11] appeared. To date, seven case reports and in total eight cases have been published on $W$. chitiniclastica infections in humans (case numbers: 1 [4], 2 [6], 3 [12], 4 [7], 5 [13], 6 [14], 7, 8 [15]). Additionally, we report on the outcome of four patients treated at Dresden University Hospital during the last three years (cases 9-12).

\section{Patients' characteristics}

Age and gender

Five patients were female (cases 1, 3, 5, 8, 12) and seven were male (cases 2, 4, 5, 6, 8, 10, 11). The medium age was 63.75 years with a range from 26 years (case 6 ) to 82 years (case 3 ). These data are summarized in Table 1.

\section{Social history/living conditions}

Information about the patient's social situation and living conditions were not provided for four of the 12 cases (cases 3, 4, 6, 9). Five patients were reported 
Table 1. Wohlfahrtiimonas chitiniclastica cases reported in the literature and own patient reports

\begin{tabular}{|c|c|c|c|c|c|c|c|}
\hline $\begin{array}{l}\text { Case } \\
\text { no. }\end{array}$ & $\begin{array}{l}\text { Age, } \\
\text { years }\end{array}$ & Gender & Region & $\begin{array}{l}\text { Underlying disease (s)/reasons for } \\
\text { hospital admission }\end{array}$ & Social conditions & $\begin{array}{l}\text { Insect } \\
\text { larvae/ } \\
\text { infested } \\
\text { wounds }\end{array}$ & Reference \\
\hline 1 & 60 & Female & $\begin{array}{l}\text { Marseille, } \\
\text { France }\end{array}$ & Alcoholism/fatigue & $\begin{array}{l}\text { Homeless, bad } \\
\text { hygienic state, } \\
\text { history of } \\
\text { alcoholism }\end{array}$ & Positive & [4] \\
\hline 2 & 70 & Male & $\begin{array}{l}\text { Buenos Aires, } \\
\text { Argentina }\end{array}$ & $\begin{array}{l}\text { Occlusive peripheral arteriopathy } \\
\text { of the lower limbs/sensory } \\
\text { impairment }\end{array}$ & $\begin{array}{l}\text { Homeless, } \\
\text { history of } \\
\text { alcoholism and } \\
\text { smoking }\end{array}$ & Negative & [6] \\
\hline 3 & 82 & Female & $\begin{array}{l}\text { Guildford, } \\
\text { UK }\end{array}$ & $\begin{array}{l}\text { Recurrent falls, hypertension, } \\
\text { chronic kidney disease, ischemic } \\
\text { heart disease, } \\
\text { hypercholesteraemia, } \\
\text { osteoarthritis/found unconscious }\end{array}$ & NP & Positive & [12] \\
\hline 4 & 64 & Male & Tartu, Estonia & $\begin{array}{l}\text { Gangrene in distal parts of the legs } \\
\text { and amputation of the feet/ } \\
\text { admission due to an accident }\end{array}$ & Alcoholism & NP & [7] \\
\hline 5 & 43 & Male & $\begin{array}{l}\text { Trivandrum, } \\
\text { India }\end{array}$ & $\begin{array}{l}\text { Diabetes, deep ulcer, cellulitis, } \\
\text { gangrene/progressing gangrenous } \\
\text { changes }\end{array}$ & $\begin{array}{l}\text { Alcoholism and } \\
\text { smoking }\end{array}$ & NP & [13] \\
\hline 6 & 26 & Male & $\begin{array}{l}\text { Salt Lake City, } \\
\text { USA }\end{array}$ & $\begin{array}{l}\text { Morbid obesity, lymphoedema, } \\
\text { cellulitis/progressive ulceral } \\
\text { disease }\end{array}$ & NP & NP & [14] \\
\hline 7 & 72 & Male & Hawaii, USA & $\begin{array}{l}\text { Stroke and deafness/found } \\
\text { unconscious }\end{array}$ & $\begin{array}{l}\text { Poor hygienic } \\
\text { conditions }\end{array}$ & Positive & {$[15]$} \\
\hline 8 & 69 & Female & Hawaii, USA & $\begin{array}{l}\text { Ruptured cerebral aneurysm and } \\
\text { right hemiparesis/sacral pain and } \\
\text { painful urination }\end{array}$ & $\begin{array}{l}\text { Homeless, poor } \\
\text { hygienic } \\
\text { conditions }\end{array}$ & Negative & [15] \\
\hline 9 & 79 & Male & $\begin{array}{l}\text { Dresden, } \\
\text { Germany }\end{array}$ & $\begin{array}{l}\text { Diabetes mellitus, coronary heart } \\
\text { disease, chronic renal failure, } \\
\text { venous insufficiency/progressive } \\
\text { ulceral disease }\end{array}$ & $\begin{array}{l}\text { Normal social } \\
\text { conditions }\end{array}$ & Negative & $\begin{array}{l}\text { This } \\
\text { publication } \\
\text { (DSM } \\
100375 \text { ) }\end{array}$ \\
\hline 10 & 43 & Male & $\begin{array}{l}\text { Dresden, } \\
\text { Germany }\end{array}$ & $\begin{array}{l}\text { Alcoholism/treatment of alcohol } \\
\text { withdrawal syndrome, exclusion } \\
\text { of tuberculosis }\end{array}$ & $\begin{array}{l}\text { Homeless, } \\
\text { alcoholism, } \\
\text { ulceral disease }\end{array}$ & Negative & $\begin{array}{l}\text { This } \\
\text { publication } \\
\text { (DSM } \\
100374)\end{array}$ \\
\hline 11 & 78 & Female & $\begin{array}{l}\text { Dresden, } \\
\text { Germany }\end{array}$ & $\begin{array}{l}\text { Severe obesity, chronic venous } \\
\text { insufficiency, arterial } \\
\text { hypertension, chronic heart failure } \\
\text { NYHA II/progressive ulceral } \\
\text { disease }\end{array}$ & $\begin{array}{l}\text { Difficult social } \\
\text { conditions }\end{array}$ & Negative & $\begin{array}{l}\text { This } \\
\text { publication } \\
\text { (DSM } \\
100676 \text { ) }\end{array}$ \\
\hline 12 & 71 & Male & $\begin{array}{l}\text { Dresden, } \\
\text { Germany }\end{array}$ & $\begin{array}{l}\text { Deep vein thrombosis, leg ulcers/ } \\
\text { speech disorder as consequence of } \\
\text { a tablet and alcohol intoxication in } \\
\text { suicidal intent }\end{array}$ & NP & Negative & $\begin{array}{l}\text { This } \\
\text { publication } \\
\text { (DSM } \\
\text { 100917) }\end{array}$ \\
\hline
\end{tabular}

NP, Not provided.

to be homeless (cases 1, 2, 5, 8, 10), one patient (case 11) was living alone under difficult social conditions (not further specified), one patient (case 9) lived under normal social conditions (not further specified) and one patient (case 11) lived under poor hygienic conditions (not further specified). Alcohol abuse was reported in four of the 12 cases (cases 1, 2, 5, 10). Two patients were smokers (cases 2 and 5). No information was given in six cases (cases 3, 4, 6-8, 12). These data are summarized in Table 1. 


\section{Underlying diseases}

No information about a basic disease was provided for three patients (cases 1, 4, 10). Five patients (cases 2, 3, 9, 11, 12) had circulatory diseases such as chronic venous insufficiency, ischaemic heart disease, arteriopathy including coronary artery disease or arterial hypertension. Two patients (cases 6 and 11) were reported to be obese and two patients (cases 5 and 9) were known to suffer from diabetes. Two patients (cases 3 and 9) additionally had renal dysfunction. One patient (case 7) was reported with a stroke and one patient (case 8) with a hemiparesis due to a ruptured cerebral aneurysm. A comprehensive summary is given in Table 1 .

\section{Infections reported in association with}

W. chitiniclastica

In four cases bloodstream infections caused by W. chitiniclastica were reported (cases 1-3, 7). In case 7 E. coli was detected in addition to W. chitiniclastica. One patient (case 4) was admitted to hospital due to a necrotizing skin infection. Two patients (cases 5 and 6) suffered from cellulitis. Case 5 additionally suffered from a deep ulcer which progressed to osteomyelitis. Five patients (cases 8-12) suffered from infected ulcers. These data are summarized in Table 2.

\section{Monomicrobial vs. polymicrobial infection}

In four cases $W$. chitiniclastica was the only bacterium which could be identified and in eight cases at least one additional bacterium could be identified or $W$. chitiniclastica was part of a polymicrobial spectrum. In four cases, W. chitiniclastica was isolated from blood cultures, in one case the samples were taken during surgery and seven samples were taken from skin-related diseases (e.g. ulcers). In cases 1, 2 and $5 \mathrm{~W}$. chitiniclastica was the only bacterium isolated and in case 3 the organism was isolated from primary blood cultures taken upon the patient's admission to hospital. However, further cultures grew in this patient: Proteus mirabilis, Providencia rettgeri and Staphylococcus aureus. Eight cases (4, 6-12) suffered from a polymicrobial infection where $W$. chitiniclastica was isolated together with other sepsis-causing pathogens. In case 4 Myroides odoratimimus was additionally detected, in case $6 P$. vulgaris, Klebsiella pneumoniae, Acinetobacter lwoffii and $S$. aureus were identified, in case 7 both $W$. chitiniclastica and Escherichia coli were detected in the blood culture, in case $8 \mathrm{~W}$. chitiniclastica was detected together with S. aureus, Aeromonas spp., Streptococcus simulans and Bacteroides fragilis. In case 9, E. coli and bacteria of the anaerobic skin flora (without further characterization) were detected. Blood cultures of case 10 grew skin flora together with $P$. mirabilis. In case 11 normal aerobic skin flora, Proteus vulgaris, $S$. aureus, Morganella morganii, Serratia marcescens and $W$. chitiniclastica were detected, and in case 12 normal aerobic skin flora, P. mirabilis, Pseudomonas aeruginosa and Providencia stuartii were identified (Table 2).

\section{Antibiotic treatment and patient outcome}

Nine of 12 patients received antibiotic treatment, mostly $\beta$-lactams (e.g. penicillins and cephalosporins) and quinolones. Treatment strategy was changed in five patients (second-line antibiotics). Two out of 12 patients died. Case 1 was effectively treated with $2 \mathrm{~g} / \mathrm{d}$ ceftriaxone. Case 2 received a combination of $400 \mathrm{mg}$ ciprofloxacin every $12 \mathrm{~h}$ and $1.5 \mathrm{~g}$ ampicillin/ sulbactam every $6 \mathrm{~h}$. For case 3, $750 \mathrm{mg}$ cefuroxime and $500 \mathrm{mg}$ metronidazole were administered 3 times a day and $500 \mathrm{mg}$ clarithromycin twice a day. The therapy was changed to $500 \mathrm{mg}$ flucloxacillin four times a day. The patient did not survive. Case 4 received amoxicillin/clavulanate for 8 days and the outcome was positive. There is no information about antibiotic treatment for case 5. Case 6 received a 10-day course of cefpodoxime. Case 7 was given piperacillin/tazobactam, clindamycin and vancomycin. This patient died 1 day after admission. Case 8 initially received ceftaroline which was changed later to meropenem. For case 9 a 4-day antibiotic treatment with $500 \mathrm{mg}$ levofloxacin twice a day and $600 \mathrm{mg}$ clindamycin three times a day was performed. Cases 10 12 did not receive any antibiotic treatment. These data are summarized in Table 2.

\section{Geographical distribution and epidemiological aspects}

Cases 1 (Marseille, France), 3 (Guilford, UK), 4 (Tartu, Estonia), 9-12 (Dresden, Germany) were reported from European countries. Case 2 was reported from Argentina (Buenos Aires) and case 5 from India (Trivandrum). Three cases were reported form North America (cases 6-8). Table 1 summarizes the geographical distribution of $W$. chitiniclastica isolates presented in this review. 
Table 2. Overview of strain sampling, methods of identification, antimicrobial treatment, patients' outcome and case rating

\begin{tabular}{|c|c|c|c|c|c|c|c|}
\hline Case no. [ref.] & Source & $\begin{array}{l}\text { Bacteria } \\
\text { identified }\end{array}$ & Methods of identification & Antibiotics, 1st line & Antibiotics, 2nd line & Outcome & Rating \\
\hline $1[4]$ & Blood culture & W. chitiniclastica & $\begin{array}{l}\text { 16S rRNA gene } \\
\text { sequencing (homology: } \\
\text { NP) }\end{array}$ & Ceftriaxone $2 \mathrm{~g} / \mathrm{d}$ & NA & Survived & $\begin{array}{l}\text { Invasive infection caused } \\
\text { by } W . \text { chitiniclastica }\end{array}$ \\
\hline $2[6]$ & Blood culture & $W$. chitiniclastica & $\begin{array}{l}\text { API } 20 \mathrm{NE} \\
\text { misidentification of } \\
W . \text { chitiniclastica as } \\
B . \text { diminuta or } O \text {. } \\
\text { urethralis } \\
\text { 16S rRNA gene } \\
\text { sequencing (homology: } \\
99 \% \text { ) }\end{array}$ & $\begin{array}{l}\text { Ciprofloxacin }(400 \mathrm{mg} \text {, } \\
2 \mathrm{x} / \mathrm{d}) \text { and ampicillin } \\
(1 \cdot 5 \mathrm{~g}, 4 \mathrm{x} / \mathrm{d})\end{array}$ & $\begin{array}{l}\text { Ceftazidime and } \\
\text { amikacin }\end{array}$ & Fatal & $\begin{array}{l}\text { Invasive infection caused } \\
\text { by } W . \text { chitiniclastica }\end{array}$ \\
\hline $3[12]$ & Blood culture & W. chitiniclastica & $\begin{array}{l}\text { MALDI-TOF MS (scores: } \\
2 \cdot 264,2 \cdot 200 \text { ) } \\
\text { 16S rRNA gene } \\
\text { sequencing (homology: } \\
\text { NP) }\end{array}$ & $\begin{array}{l}\text { Cefuroxime }(750 \mathrm{mg}, 3 \mathrm{x} / \mathrm{d}) \\
\text { metronidazole }(500 \mathrm{mg}, 2 \\
\mathrm{x} / \mathrm{d}) \text { clarithromycin }(500 \\
\mathrm{mg}, 2 \mathrm{x} / \mathrm{d}, \text { for } 7 \text { days }), \\
\text { topical fusidic acid and } \\
\text { chloramphenicol }\end{array}$ & $\begin{array}{l}\text { Flucoxacillin }(500 \mathrm{mg}, \\
4 \text { x/d, p.o. })\end{array}$ & Surived & $\begin{array}{l}\text { Invasive infection caused } \\
\text { by } W . \text { chitiniclastica }\end{array}$ \\
\hline 4 [7] & $\begin{array}{l}\text { Bone samples } \\
\text { collected } \\
\text { during surgery } \\
\text { (resection site) }\end{array}$ & $\begin{array}{l}\text { W. chitiniclastica } \\
\text { M. } \\
\text { odoratimimus }\end{array}$ & $\begin{array}{l}\text { VITEK } 2 \text { misidentification } \\
\text { of } W \text {. chitiniclastica as } \\
C \text {. testosteroni }(96 \%) \\
\text { MALDI-TOF MS } \\
\text { (scores: } 2 \cdot 350,2 \cdot 389 \text {, } \\
2 \cdot 259 \text { ) } \\
\text { 16S rRNA gene } \\
\text { sequencing (homology: } \\
99 \% \text { ) }\end{array}$ & $\begin{array}{l}\text { Amoxicillin/clavulanate for } \\
8 \text { days }\end{array}$ & NA & Survived & $\begin{array}{l}\text { Polymicrobial } \\
\text { infection, (unclear if } \\
W . \text { chitiniclastica was } \\
\text { really the causative } \\
\text { agent) }\end{array}$ \\
\hline $5[13]$ & $\begin{array}{l}\text { Swabs from } \\
\text { deep site of } \\
\text { ulcer }\end{array}$ & $W$. chitiniclastica & $\begin{array}{l}\text { MALDI-TOF MS (score: } \\
\text { NP) } \\
\text { 16S rRNA gene } \\
\text { sequencing (homology: } \\
\text { ND) }\end{array}$ & $\begin{array}{l}\text { Cefoperaxone/sulbactam } \\
(1.5 \mathrm{~g}, 2 \mathrm{x} / \mathrm{d})\end{array}$ & $\begin{array}{l}\text { Cefpodoxime } \\
(2 \mathrm{x} / \mathrm{d}, \text { p.o. for } 2 \text { weeks })\end{array}$ & Survived & $\begin{array}{l}\text { Infection caused by } \\
W . \text { chitiniclastica }\end{array}$ \\
\hline $6[14]$ & $\begin{array}{l}\text { Swab from the } \\
\text { right leg }\end{array}$ & $\begin{array}{l}\text { W. chitiniclastica } \\
\text { P. vulgaris } \\
\text { K. pneumoniae } \\
\text { S. aureus }\end{array}$ & $\begin{array}{l}\text { VITEK } 2 \text { misidentification } \\
\text { of } W \text {. chitiniclastica as } A \text {. } \\
\text { lwoffii }(96 \%) \\
\text { MALDI-TOF MS } \\
\text { (scores: } 2 \cdot 253,2 \cdot 296 \text {, } \\
2 \cdot 229) \\
\text { 16S rRNA gene } \\
\text { sequencing (homology: } \\
\text { NP) }\end{array}$ & Cefpodoxime (for 10 days) & NA & Survived & $\begin{array}{l}\text { It was unresolved if } \\
W . \text { chitiniclastica } \\
\text { was the causative agent } \\
\text { of the disease }\end{array}$ \\
\hline
\end{tabular}


Table 2 (cont.)

\begin{tabular}{|c|c|c|c|c|c|c|c|}
\hline Case no. [ref.] & Source & $\begin{array}{l}\text { Bacteria } \\
\text { identified }\end{array}$ & Methods of identification & Antibiotics, 1st line & Antibiotics, 2nd line & Outcome & Rating \\
\hline 7 [15] & Blood culture & $\begin{array}{l}\text { W. chitiniclastica } \\
\text { E. coli }\end{array}$ & $\begin{array}{l}\text { 16S rRNA gene } \\
\text { sequencing (homology: } \\
100 \% \text { ) }\end{array}$ & $\begin{array}{l}\text { Piperacillin/tazobactam, } \\
\text { clindamycin, vancomycin }\end{array}$ & NA & Fatal & $\begin{array}{l}\text { Blood culture proved } \\
W . \text { chitiniclastica to be } \\
\text { relevant }\end{array}$ \\
\hline $8[15]$ & $\begin{array}{l}\text { Swabs from } \\
\text { deep wound }\end{array}$ & $\begin{array}{l}\text { W. chitiniclastica } \\
\text { S. aureus } \\
\text { Aeromonas spp. } \\
\text { S. simulans, } \\
\text { B. fragilis }\end{array}$ & $\begin{array}{l}\text { 16S rRNA gene } \\
\text { sequencing (homology: } \\
100 \% \text { ) }\end{array}$ & Ceftaroline fosamil & Meropenem & Survived & $\begin{array}{l}\text { Clinical relevance of } \\
W . \text { chitiniclastica could } \\
\text { not be determined }\end{array}$ \\
\hline $\begin{array}{l}9 \text { This } \\
\text { publication } \\
\text { (DSM } \\
100375)\end{array}$ & $\begin{array}{l}\text { Swabs from } \\
\text { ulcer of the } \\
\text { left leg }\end{array}$ & $\begin{array}{l}\text { W. chitiniclastica } \\
\text { E. coli }\end{array}$ & $\begin{array}{l}\text { VITEK } 2 \text { misidentification } \\
\text { of } W \text {. chitiniclastica as } \\
\text { A. lwoffii }(96 \%) \\
\text { MALDI-TOF MS } \\
\text { (score: } 2 \cdot 262) \\
\text { 16S rRNA gene } \\
\text { sequencing (homology: } \\
100 \% \text { ) }\end{array}$ & $\begin{array}{l}\text { Cefuroxime }(500 \mathrm{mg}, 2 \mathrm{x} / \mathrm{d} \\
\text { for } 5 \text { days) }\end{array}$ & $\begin{array}{l}\text { Levofloxacin }(500 \mathrm{mg} \text {, } \\
2 \mathrm{x} / \mathrm{d} \text { for } 9 \text { days }) \\
\text { clindamycin }(600 \mathrm{mg} \text {, } \\
3 \mathrm{x} / \mathrm{d} \text { for } 4 \text { days })\end{array}$ & Survived & $\begin{array}{l}\text { Colonization, no signs of } \\
\text { infection or } \\
\text { inflammation }\end{array}$ \\
\hline $\begin{array}{l}10 \text { This } \\
\text { publication } \\
\text { (DSM } \\
100374)\end{array}$ & $\begin{array}{l}\text { Swabs from } \\
\text { ulcers }\end{array}$ & $\begin{array}{l}\text { W. chitiniclastica } \\
\text { P. mirabilis }\end{array}$ & $\begin{array}{l}\text { VITEK } 2 \text { misidentification } \\
\text { of } W \text {. chitiniclastica as } \\
\text { A. Iwoffii }(96 \%) \\
\text { MALDI-TOF MS } \\
\text { (score: } 2 \cdot 441) \\
\text { 16S rRNA gene } \\
\text { sequencing (homology: } \\
100 \% \text { ) }\end{array}$ & No antibiotic treatment & NA & Survived & $\begin{array}{l}\text { Colonization, no signs of } \\
\text { infection or } \\
\text { inflammation }\end{array}$ \\
\hline $\begin{array}{l}11 \text { This } \\
\text { publication } \\
\text { (DSM } \\
100676)\end{array}$ & $\begin{array}{l}\text { Swabs from } \\
\text { ulcers }\end{array}$ & $\begin{array}{l}\text { W. chitiniclastica } \\
\text { P. mirabilis } \\
\text { S. aureus } \\
\text { S. marcescens } \\
\text { M. morganii }\end{array}$ & $\begin{array}{l}\text { VITEK } 2 \text { misidentification } \\
\text { of } W . \text { chitiniclastica as } \\
R . \text { radiobacter }(99 \%) \\
\text { MALDI-TOF MS } \\
\text { (score: } 2 \cdot 019 \text { ) } \\
\text { 16S rRNA gene } \\
\text { sequencing (homology: } \\
100 \% \text { ) }\end{array}$ & No antibiotic treatment & NA & Survived & $\begin{array}{l}\text { Colonization, no signs of } \\
\text { infection or } \\
\text { inflammation }\end{array}$ \\
\hline
\end{tabular}




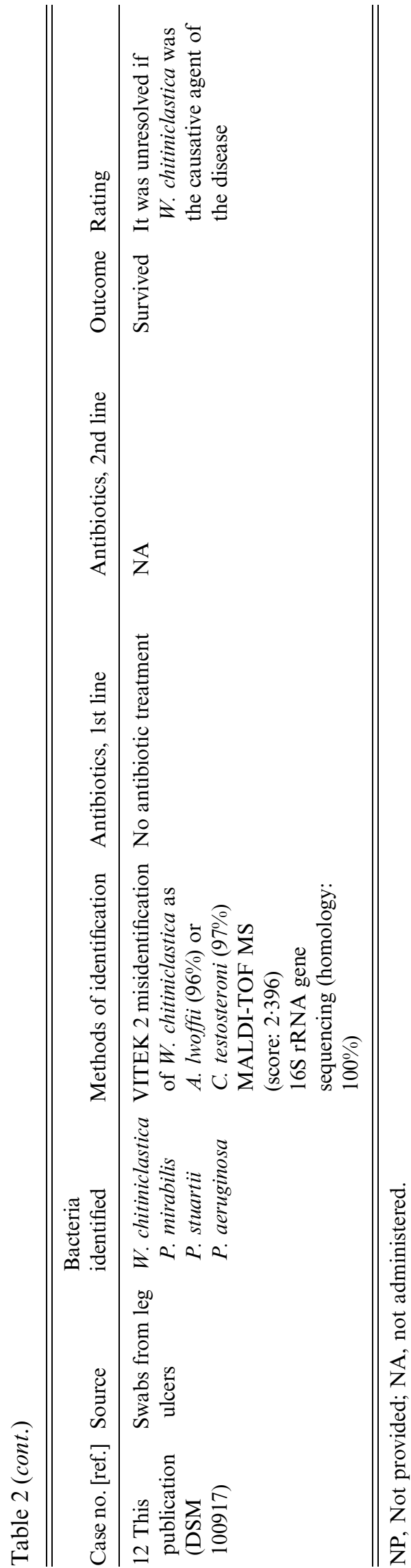

\section{Methods of identification}

MALDI-TOF MS

$W$. chitiniclastica was successfully identified by MALDI-TOF MS [16] in cases 3 (scores 2.264 and 2.200), 4 (scores 2.350, 2.389 and 2.259), 5 (score not provided), 6 (scores $2 \cdot 253,2 \cdot 296$ and $2 \cdot 229$ ), 9 (score 2.262), 10 (2.441), 11 (score 2.019) and 12 (score 2.396). Figure 1 shows the spectra of the W. chitiniclastica-type strain (DSM 18708) and of the four strains isolated at our hospital (DSM 100375, DSM 100374, DSM 100676, DSM 100917). The MALDI-TOF MS scores of all strains are summarized in Table 2. Scores show the reliability of the species identification. Scores above 2.300 represent a highly probable species identification, a score between 2.000 and 2.300 indicates a secure species identification, a score between 1.700 and 2.000 represents a probable species identification and a score below $1 \cdot 700$ is not reliable [16].

\section{$16 S$ rDNA sequencing}

W. chitiniclastica was correctly identified by $16 \mathrm{~S}$ rRNA gene sequencing in cases 1 (homology data not provided), 2 (99\% homology), 3 (homology data not provided), 4 (99\% homology), 5 (homology data not provided), 6 (homology data not provided), 7 (100\% homology), 8 (100\% homology), 9 (100\% homology), 10 (100\% homology), 11 (100\% homology) and 12 (100\% homology). The data are summarized in Table 2.

\section{Biochemical testing using VITEK 2}

In cases 1 and 5 phenotypic analysis failed to identify the bacteria. However, the tests applied were not further described. In case 2 API 20 NE identified the strain as Brevundimonas diminuta or Oligella urethralis with a low probability of $88.5 \%$. In case 4 the identification utilizing VITEK 2 revealed Comamonas testosteroni with a probability of $99 \%$. However, 16S rDNA sequencing showed a homology to C. testosterone-type strain DSM 50244 with only $82 \%$. In the following three cases, using VITEK 2, $W$. chitiniclastica was misidentified as $A$. lwoffii, i.e. cases 6 (probability 96\%), 9 (probability 99\%) and 10 (probability 96\%). The biochemical reactions detected by VITEK 2, using the GN card, are presented in Supplementary Table S1. The substrates on the GN card are listed in table 7 of the Encyclopedia of Rapid Microbiological Methods [17]. In addition to the $W$. chitiniclastica-type strain 

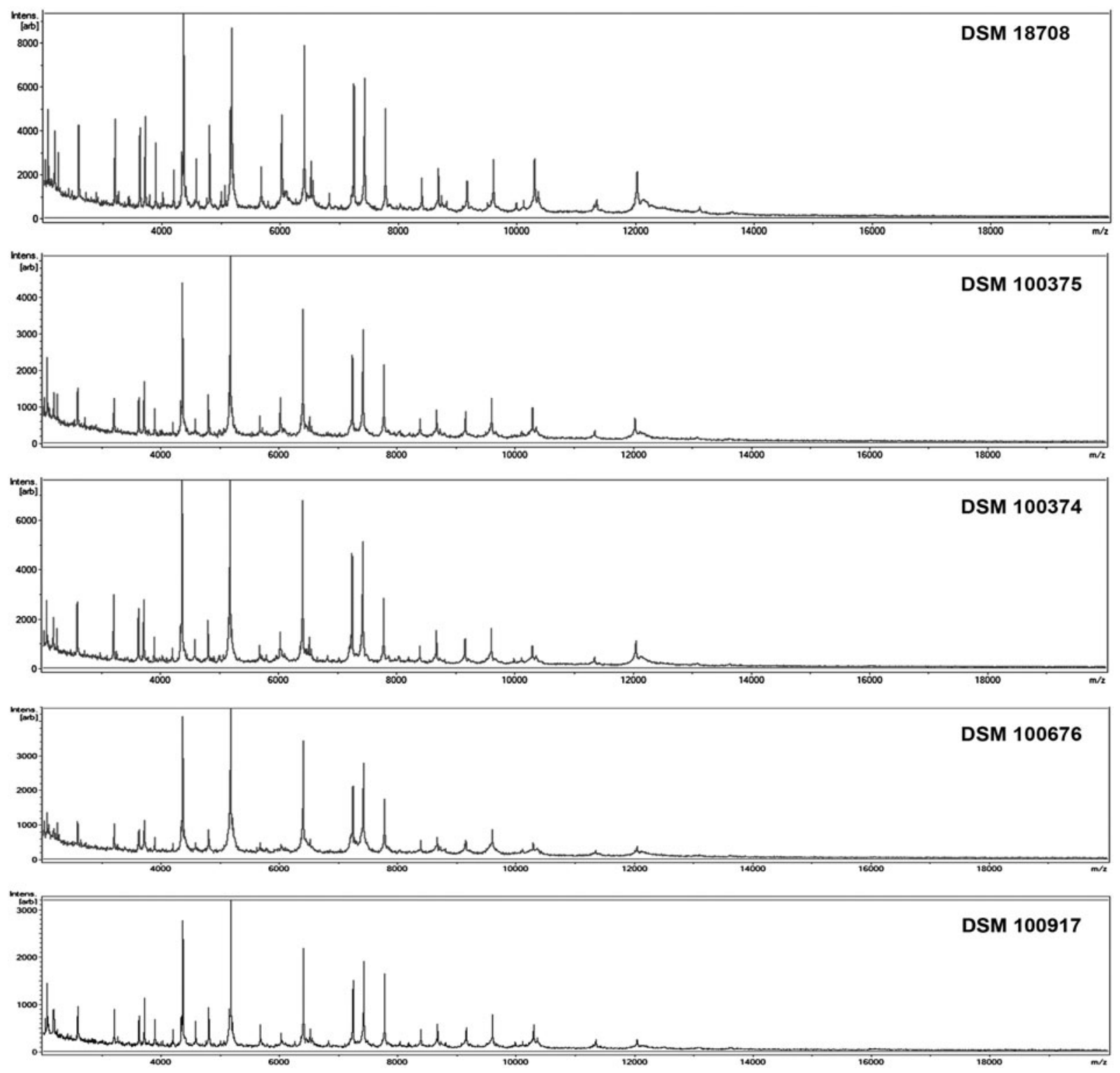

Fig. 1. MALDI-TOF MS spectra of the W. chitiniclastica-type strain and our isolates. Shown are the mass spectra of the W. chitiniclastica-type strain (DSM 18708) and the four strains isolated at Dresden University Hospital: DSM 100375 (case 9); DSM 100374 (case 10); DSM 100676 (case 11); DSM 100917 (case 12).

(DSM 18708), results from the four isolates collected at Dresden University Hospital (DSM 100374, DSM 100375, DSM 100676, DSM 100917) are included.

\section{Antimicrobial susceptibility testing}

Among the group of $\beta$-lactam antibiotics, W. chitiniclastica was susceptible to penicillins, cephalosporins and carbapenems (cases 1,2, 4-12), to quinolones (cases 1, 2, 5-12), aminoglycosides (cases 1, 2, 4-12), trimethoprim/sulfamethoxazole (cases 1, 2, 4-10), colistin (case 4) or tetracycline (cases 2, 7, 8). No resistance data were provided for case 3 . Testing was performed using E-test strips (BESTBION, Germany) according to the EUCAST guidelines for 2016.

In agreement with published data the type strain DSM 18708 and our isolates were also susceptible to $\beta$-lactam antibiotics, to quinolones and to tigecycline. The minimum inhibitory concentration (MIC) values are given in Table 3. Testing was performed according the guidelines using non-speciesrelated breakpoints of the European Committee on Antimicrobial Susceptibility Testing (EUCAST; http://www.eucast.org/). Additionally, we tested our strains against trimethoprim/sulfamethoxazole, 
fosfomycin, colistin, gentamicin, amikacin, erythromycin and azithromycin (Table 3). However, EUCAST non-species-related breakpoints are not available for these antibiotics. MIC values ranged from $0.032 \mu \mathrm{g} / \mathrm{ml}$ to $4 \mu \mathrm{g} / \mathrm{ml}$, except for fosfomycin, which revealed MIC values $>1024 \mu \mathrm{g} / \mathrm{ml}$ in all isolates presented in Table 3.

\section{DISCUSSION}

W. chitiniclastica was first isolated from samples of the obligate parasitic fly Woh. magnifica in 2008 [1, 2, 11]. The sequenced $W$. chitiniclastica strain $\mathrm{SH} 04$ has a genome size of $2 \cdot 12 \mathrm{Mb}$, with an average $\mathrm{G} / \mathrm{C}$ content of $43 \cdot 48 \%$. It contains 2006 open reading frames [11]. Further investigations revealed a high similarity to I. larvae, another bacterial species which is also commonly found in flies $[1,5]$. The transmission of these bacteria therefore seems to be closely linked to these insects. Female flies of the species Woh. magnifica deposit eggs in traumatic skin lesions or on mucosal surfaces of the affected host [18]. The developed larvae feed within the tissue leading to significant destruction which may even result in a fatal outcome [19]. After 57 days the larvae fall to the ground and pupate. At this stage of the insect's life cycle the enzyme chitinase may play an important role by supporting the insects in their pupation [20].

In addition to the close link of $W$. chitiniclastica to certain flies, the bacteria have recently been detected in arsenic-affected soils from Bangladesh [21]. Furthermore, Matos and co-workers found W. chitiniclastica in multiple samples of chicken meat purchased in Brazilian supermarkets [22]. The occurrence of this bacterium indicates poor sanitary conditions and is contrary to good manufacturing practice [22]. Because the fly Woh. magnifica does not occur in South America another route of infection via C. megacephala as depositor of $W$. chitiniclastica was suggested.

To date, four well documented cases (cases 1-4) of invasive/bloodstream infections caused by $W$. chitiniclastica have been reported [4, 6, 7, 12]. It is probable that the bacteria are transmitted to the tissue of the host by larvae and may reach the bloodstream while being distributed in the tissue. In these case descriptions, $W$. chitiniclastica was the only bacterium isolated. One patient died due to septic shock caused by $W$. chitiniclastica [6].

However, in cases 5, 6 and 9-12 W. chitiniclastica was part of a polymicrobial spectrum and therefore it is impossible to clarify if $W$. chitiniclastica was the sole cause of infection (see references in Table 2). Mouse infection experiments published recently by Qi et al. revealed $W$. chitiniclastica being pathogenic to mice only at large doses, i.e. $10^{9}-10^{10}$ colonyforming units per intraperitoneal injection [10]. In cases 7 and 8, published recently by Nogi et al., the authors report on two patients with soft tissue infection and sepsis [15]. In both cases $W$. chitiniclastica was not the sole cause of the disease [15]. In case 7 E. coli was additionally identified and in case 8 $W$. chitiniclastica was part of a large polymicrobial spectrum consisting of aerobic and anaerobic pathogens [15].

$W$. chitiniclastica patients, their underlying diseases and cause of hospitalization are listed in Table 1. Most patients suffered from diseases affecting the skin such as ulcers (cases 9-11 [13-15]), wounds (cases 7 and 8 [15]), gangrene (cases 4 and 5 [7, 13]) or cellulitis (case 5 [13]). Patients suffered also from impairments of the cardiovascular system such as occlusive arteriopathy (case 2 [6]), hypertension (cases 3 [12] and 11), different heart diseases (cases 3 [12], 9 and 11), chronic venous insufficiency (cases 9 and 11) or deep vein thrombosis (case 12). The two patients reported by Nogi et al. (cases 7 and 8) suffered from neurological disorders, stroke and ruptured cerebral aneurysm [15]. Conditions leading to an increased probability of maggot infestation can be considered a risk factor for $W$. chitiniclastica infections. Cases 1, 2, 8 [4, 6, 15] and 10 were reported to be homeless, thus being at higher risk of being affected by myiasis. Case 3, who exhibited multiple maggots and insect larvae, was found unconscious in her garden after collapsing 72-96 h earlier [12]. Since many (especially vascular) diseases are typical for older patients it is not surprising that the mean age of $W$. chitiniclastica patients was found to be 63.75 years. Gender, however, does not seem to play a role.

The cases described here are reports from different parts of the world. At the time of writing the fly Woh. magnifica is found in continental Europe and the Middle East [2] but is unknown in the UK [4, 12], South America [6], North America [14] and Asia [13]. However, it is likely that the bacteria can be transmitted by different insects. For instance, as described in case 3, the common green bottle fly Lucilia sericata was identified as source of a W. chitiniclastica infection [12]. Furthermore, W. chitiniclastica could be isolated from the flies Chrysomya megacephala and Musca domestica [7, 23]. 
Table 3. Antibiotic susceptibility of the Wohlfahrtiimonas chitiniclastica-type strain DSM 18708 and the isolates from Dresden University Hospital

\begin{tabular}{|c|c|c|c|c|c|c|c|c|c|c|}
\hline Antibiotic & $\begin{array}{l}\text { MIC } \\
\text { DSM } \\
18708\end{array}$ & $\begin{array}{l}\text { Interpretation } \\
\text { EUCAST }\end{array}$ & $\begin{array}{l}\text { MIC } \\
\text { DSM } \\
100374\end{array}$ & $\begin{array}{l}\text { Interpretation } \\
\text { EUCAST }\end{array}$ & $\begin{array}{l}\text { MIC } \\
\text { DSM } \\
100375\end{array}$ & $\begin{array}{l}\text { Interpretation } \\
\text { EUCAST }\end{array}$ & $\begin{array}{l}\text { MIC } \\
\text { DSM } \\
100676\end{array}$ & $\begin{array}{l}\text { Interpretation } \\
\text { EUCAST }\end{array}$ & $\begin{array}{l}\text { MIC } \\
\text { DSM } \\
100917\end{array}$ & $\begin{array}{l}\text { Interpretation } \\
\text { EUCAST }\end{array}$ \\
\hline Ampicillin & 0.032 & $\mathrm{~S}$ & $0 \cdot 064$ & $\mathrm{~S}$ & $0 \cdot 064$ & $\mathrm{~S}$ & 0.064 & $\mathrm{~S}$ & $0 \cdot 064$ & $\mathrm{~S}$ \\
\hline $\begin{array}{l}\text { Piperacillin/ } \\
\text { tazobactam }\end{array}$ & 0.032 & $\mathrm{~S}$ & $0 \cdot 125$ & $\mathrm{~S}$ & 0.064 & $\mathrm{~S}$ & 0.032 & $\mathrm{~S}$ & $0 \cdot 125$ & $\mathrm{~S}$ \\
\hline Ceftazidime & $0 \cdot 016$ & $\mathrm{~S}$ & 0.032 & $\mathrm{~S}$ & $0 \cdot 064$ & $\mathrm{~S}$ & $0 \cdot 064$ & $\mathrm{~S}$ & 0.064 & $\mathrm{~S}$ \\
\hline Cefepime & $0 \cdot 064$ & $\mathrm{~S}$ & $0 \cdot 016$ & $\mathrm{~S}$ & $0 \cdot 032$ & $\mathrm{~S}$ & $0 \cdot 064$ & $\mathrm{~S}$ & $0 \cdot 016$ & $\mathrm{~S}$ \\
\hline Aztreonam & $0 \cdot 016$ & $\mathrm{~S}$ & $0 \cdot 016$ & $\mathrm{~S}$ & $0 \cdot 016$ & $\mathrm{~S}$ & $0 \cdot 032$ & $\mathrm{~S}$ & $0 \cdot 016$ & $\mathrm{~S}$ \\
\hline Imipenem & $0 \cdot 125$ & $\mathrm{~S}$ & $0 \cdot 125$ & $\mathrm{~S}$ & $0 \cdot 125$ & $\mathrm{~S}$ & $0 \cdot 016$ & $\mathrm{~S}$ & $0 \cdot 125$ & $\mathrm{~S}$ \\
\hline Meropenem & $0 \cdot 004$ & $\mathrm{~S}$ & $0 \cdot 008$ & $\mathrm{~S}$ & 0.004 & $\mathrm{~S}$ & $0 \cdot 125$ & $\mathrm{~S}$ & 0.004 & $S$ \\
\hline Ciprofloxacin & $0 \cdot 032$ & $\mathrm{~S}$ & $0 \cdot 016$ & $\mathrm{~S}$ & $0 \cdot 016$ & $\mathrm{~S}$ & $0 \cdot 016$ & $\mathrm{~S}$ & $0 \cdot 004$ & S \\
\hline Moxifloxacin & $0 \cdot 125$ & $\mathrm{~S}$ & 0.008 & $\mathrm{~S}$ & $0 \cdot 125$ & $\mathrm{~S}$ & 0.032 & $\mathrm{~S}$ & 0.032 & $\mathrm{~S}$ \\
\hline Tigecycline & $0 \cdot 032$ & $\mathrm{~S}$ & $0 \cdot 125$ & $\mathrm{~S}$ & $0 \cdot 125$ & $\mathrm{~S}$ & $0 \cdot 125$ & $\mathrm{~S}$ & $0 \cdot 125$ & $\mathrm{~S}$ \\
\hline $\begin{array}{l}\text { Trimethoprim/ } \\
\text { sulfamethozxazole }\end{array}$ & $0 \cdot 125$ & IE & $0 \cdot 125$ & IE & $0 \cdot 125$ & $\mathrm{IE}$ & $0 \cdot 25$ & IE & $0 \cdot 125$ & IE \\
\hline Fosfomycin & 1024 & $\mathrm{IE}$ & 1024 & IE & 1024 & $\mathrm{IE}$ & 1024 & IE & 1024 & IE \\
\hline Colistin & 1 & IE & 1 & IE & 1 & $\mathrm{IE}$ & 1 & IE & 1 & IE \\
\hline Gentamicin & $0 \cdot 5$ & $\mathrm{IE}$ & 1 & IE & $0 \cdot 5$ & $\mathrm{IE}$ & 1 & $\mathrm{IE}$ & 1 & IE \\
\hline Amikacin & $0 \cdot 5$ & IE & 1 & IE & 1 & $\mathrm{IE}$ & 1 & $\mathrm{IE}$ & 1 & IE \\
\hline Erythromycin & 2 & IE & 2 & IE & 4 & IE & 2 & $\mathrm{IE}$ & 2 & IE \\
\hline Azithromycin & $0 \cdot 5$ & $\mathrm{IE}$ & 1 & $\mathrm{IE}$ & $0 \cdot 5$ & IE & $0 \cdot 5$ & $\mathrm{IE}$ & 1 & $\mathrm{IE}$ \\
\hline
\end{tabular}

MIC, Minimum inhibitory concentration; S, susceptible; IE, insufficient evidence; EUCAST, European Committee on Antimicrobial Susceptibility Testing [breakpoint tables for interpretation of MICs and zone diameters, version 6.0, 2016 (http://www.eucast.org/fileadmin/src/media/PDFs/EUCAST_files/Breakpoint_tables/v_6.0_Breakpoint_table. pdf)]. 
Based on the current literature and our own experience biochemical approaches such as API (Analyical Profile Index, bioMérieux, Germany) or VITEK 2 (bioMérieux) to identify $W$. chitiniclastica lead to wrong and misleading results. The biochemical profiles, obtained by VITEK 2, of the four isolates from Dresden University Hospital and two type strains are given in Supplementary Table S1. Almuzara et al. used the API $20 \mathrm{NE}$ system which resulted in $B$. diminuta or $O$. urethralis [6]. Analyses using the VITEK 2 system identified the bacterium as $C$. testosteroni with an excellent result (99\% identitiy) or as $A$. lwoffii (96-99\% identity) (cases 6-8) [14, 15]. De Dios et al. compared the biochemical profiles of $A$. lwoffii and $W$. chitiniclastica using both VITEK 2 and API 20 NE. They revealed that both bacteria showed an identical profile except for oxidase activity (A. lwoffii is oxidase negative and $W$. chitiniclastica is oxidase positive) [14]. 16S rRNA gene sequencing and MALDI-TOF MS, however, gave reproducible and reliable identification of $W$. chitiniclastica [7, 12-15]. We have described and compared both methods in detail recently [16]. MALDI-TOF MS, however, has the advantage of speed.

Antimicrobial susceptibility testing was performed in 11 out of the 12 cases and revealed that $W$. chitiniclastica is susceptible to $\beta$-lactam antibiotics, quinolones, aminoglycosides, colistin, trimethoprim/ sulfamethoxazole and tetracyclin as reported in the literature $[4,6,7,13-15]$ and measured in our isolates given in Table 3. According to our investigations the MIC value determined for fosfomycin is very high (Table 3). This observation is in accord with results from Matos and co-workers who also found MIC values of $>32 \mu \mathrm{g} / \mathrm{ml}$ in the samples they investigated [22]. These results suggest that $W$. chitiniclastica is intrinsically resistant to fosfomycin. In the same way it can be assumed that $W$. chitiniclastica is (due to the low MIC values determined in vitro) susceptible to tigecycline (Table 3). Most patients received an antimicrobial treatment using $\beta$-lactam antibiotics with a combination of quinolones or aminoglycosides. All patients except two $[6,15]$ survived. The fatal outcomes, however, may be explained by these patients poor condition upon admission to the hospital. Additionally, for case 7, described by Nogi et al., it remains unclear if $W$. chitiniclastica or $E$. coli were responsible for the patient's septic condition [15]. Table 3 shows the antimicrobial profiles measured for the $W$. chitiniclastica-type strain (DSM 18708) and the four isolates from our hospital (DSM 100374, DSM 100375, DSM 100676, DSM 100917).
In conclusion, $W$. chitiniclastica is a recently described bacterial pathogen whose appearance is linked to certain flies. These insects carry and distribute this bacterium to a host. Since biochemistry-based approaches fail to correctly identify this bacterium MALDI-TOF MS or 16S rRNA gene sequencing are required for confirmation. Since $W$. chitiniclastica is susceptible to a wide range of antibiotics, treatment with $\beta$-lactam antibiotics alone or combined with quinolones or aminoglycosides may successfully be administered. Due to the few data currently available, more epidemiological research and an awareness that this bacterium can cause serious infections is needed. For rapid, economic and reliable detection MALDI-TOF MS will be the right diagnostic tool [16].

\section{SUPPLEMENTARY MATERIAL}

For supplementary material accompanying this paper visit https://doi.org/10.1017/S0950268816003411.

\section{ACKNOWLEDGEMENTS}

The authors did not receive funding for this work. We thank Dr. Bärbel Fösel and PD Dr. Sabine Gronow for including our strains in the DSMZ Open collection.

\section{DECLARATION OF INTEREST}

None.

\section{REFERENCES}

1. Toth EM, et al. Wohlfahrtiimonas chitiniclastica gen. nov., sp. nov., a new gamma proteobacterium isolated from Wohlfahrtia magnifica (Diptera: Sarcophagidae). International Journal of Systematic and Evolutionary Microbiology 2008; 58: 976-981.

2. Robbins K, Khachemoune A. Cutaneous myiasis: a review of the common types of myiasis. International Journal of Dermatology 2010; 49: 1092-1098.

3. Lee JK, et al. Wohlfahrtiimonas larvae sp. nov., isolated from the larval gut of Hermetia illucens (Diptera: Stratiomyidae). Antonie Van Leeuwenhoek 2014; 105: 15-21.

4. Rebaudet S, et al. Wohlfahrtiimonas chitiniclastica bacteremia in homeless woman. Emerging Infectious Diseases 2009 15: 985-987.

5. Toth EM, et al. Proposal to replace the illegitimate genus name Schineria Toth et al. 2001 with the genus name Ignatzschineria gen. nov. and to replace the illegitimate combination Schineria larvae Toth et al. 2001 with Ignatzschineria larvae comb. nov. International 
Journal of Systematic and Evolutionary Microbiology 2007; 57: 179-180.

6. Almuzara MN, et al. First case of fulminant sepsis due to Wohlfahrtiimonas chitiniclastica. Journal of Clinical Microbiology 2011; 49: 2333-2335.

7. Koljalg S, et al. First report of Wohlfahrtiimonas chitiniclastica from soft tissue and bone infection at an unusually high northern latitude. Folia Microbiologica (Praha) 2014; 11.

8. Thaiwong T, et al. First report of emerging zoonotic pathogen Wohlfahrtiimonas chitiniclastica in the United States. Journal of Clinical Microbiology 2014; 52: 2245-2247.

9. Josue DD, et al. Endocarditis Associated with Wohlfahrtiimonas chitiniclastica in a Short-beaked Common Dolphin (Delphinus delphis). Journal of Wildlife Diseases 2015; 51: 283-286.

10. Qi J, et al. Identification of Wohlfahrtiimonas chitiniclastica isolated from an infected cow with hoof fetlow, China. Infection, Genetics and Evolution 2016; 41: 174-176.

11. Cao XM, et al. Complete genome sequence of Wohlfahrtiimonas chitiniclastica strain $\mathrm{SH} 04$, isolated from Chrysomya megacephala collected from Pudong International Airport in China. Genome Announcements 2013; 1: e0011913.

12. Campisi L, Mahobia N, Clayton JJ. Wohlfahrtiimonas chitiniclastica bacteremia associated with myiasis, United Kingdom. Emerging Infectious Diseases 2015; 21: 1068-1069.

13. Suryalatha K, John J, Thomas S. Wohlfahrtiimonas chitiniclastica-associated osteomyelitis: a rare case report. Future Microbiology 2015; 10: 1107-1109.

14. de Dios A, et al. First report of Wohlfahrtiimonas chitiniclastica Isolation from a patient with cellulitis in the
United States. Journal of Clinical Microbiology 2015; 53: 3942-3944.

15. Nogi M, Bankowski MJ, Pien FD. Wohlfahrtiimonas chitiniclastica Infections in 2 Elderly Patients, Hawaii. Emerging Infectious Diseases 2016; 22: 567-568.

16. Schröttner $\mathbf{P}$, et al. Identification of rare bacterial pathogens by $16 \mathrm{~S}$ rRNA gene sequencing and MALDI-TOF MS. Journal of Visualized Experiments 2016; 11; 113.

17. Pincus DH. Microbial identification using the bioMérieux VITEK 2 system. In: Miller MJ, ed. Encyclopedia of Rapid Microbiological Methods. River Grove: DHI Publishing, 2005, pp. 1-32.

18. Ruiz-Martinez I, et al. Postembryonic development of Wohlfahrtia magnifica (Schiner, 1862) (Diptera: Sarcophagidae). Journal of Parasitology 1989; 75: 531-539.

19. Goddard J. Flies whose maggots cause myiasis in humans. In: Physician's Guide to Arthropods of Medical Importance, 5th edn. Boca Raton: CRC Press, 2007, pp. 201-20.

20. Toth E, et al. Schineria larvae gen.nov., sp.nov., isolated from the 1st and 2nd larval stages of Wohlfahrtia magnifica (Diptera: Sarcophagidae). International Journal of Systematic and Evolutionary Microbiology 2001; 51: 401-407.

21. Sanyal SK, et al. Diversity of arsenite oxidase gene and arsenotrophic bacteria in arsenic affected Bangladesh soils. AMB Express 2016; 6: 21.

22. Matos J, et al. First report of the emerging zoonotic agent Wohlfahrtiimonas chitiniclastica isolated from a retail frozen chicken in Rio de Janeiro, Brazil. Antonie Van Leeuwenhoek 2016; 109: 729-734.

23. Gupta AK, et al. Phylogenetic characterization of bacteria in the gut of house flies (Musca domestica L.). FEMS Microbiology Ecology 2012; 79: 581-593. 